p-ISSN 1693-9484,e-ISSN : 2621-8313

Majalah Ilmiah Bahari Jogja (MIBJ)

Vol. 19 No. 2, Juli 2021

$(137-150)$

DOI: $10.33489 /$ mibj.v19i2.268

(C) 2021 Sekolah Tinggi Maritim Yogyakarta

\title{
Power Management System (PMS) Sebagai Kontrol Utama Dalam Perkembangan Power Listrik Kapal
}

\author{
Fajar Pujiyanto $^{1}$, Eka Darmana ${ }^{2 *}$ \\ ${ }^{1,2}$ Program Studi Teknika, Fakultas Teknik, Politeknik Bumi AKPELNI \\ Jl. Pawiyatan Luhur II, Bendanduwur, Semarang \\ *corresponding author. Email: ekadarmana@akpelni.ac.id
}

\begin{abstract}
Abstrak
Power listrik kapal mulai diperkenalkan pada abad 19, listrik sebagai sumber energi pengoperasian kapal digunakan untuk penerangan, komunikasi, navigasi, monitoring, alarm system, menjalankan motor listrik, dan instalasi high voltage penggerak utama kapal. Instalasi listrik pertama kali oleh kapal komersial SS Columbia dengan power listrik DC, berlanjut kepada power listrik induksi motor AC dengan mesin diesel. Teknologi power listrik terbaru yaitu All Electric Ship (AES) oleh kapal penumpang ferry Ampere, adalah kapal pertama di dunia yang menggunakan fully battery driven dan beroperasi regular di perairan Norwegia. Saat ini engineer dunia mengembangkan desain kapal baru dengan sistem power hybrid, yaitu menyatukan dua atau lebih sumber power yang terintegrasi untuk mendapatkan power berefisiensi tinggi. Penulisan dalam paper ini menggunakan metode deskripsi kualitatif dengan mengacu kepada studi kepustakaan. Perkembangan listrik dari tiap generasi tentang sumber power listrik, kontrol automatis dan managemen power menjadi bahan untuk dibahas dalam penulisan ini. Power Management System (PMS) adalah system kontrol terintegrasi secara fungsional untuk mengoptimalkan alokasi power dan distribusi energi. PMS menjaga power listrik bekerja tanpa ada hambatan, gangguan, ataupun kegagalan sistem saat kapal beroperasi. PMS mengendalikan power secara aman dan berimbang antara pembangkit listrik dan distribusi power listrik kapal.
\end{abstract}

Kata Kunci: Kontrol Utama, Listrik Kapal, Power Management System (PMS)

\begin{abstract}
Shipboard electrical power was introduced in the 19th century, electricity as a source of energy for operating vessel is used for lighting, communication, navigation, monitoring, alarm systems, running electric motors, and high voltage installations as the main propulsion. The first electrical installation by commercial ship SS Columbia with a DC electical power, followed by an AC induction motor with a diesel engine. The new technology of electrical power is All Electric Ship (AES) by the passenger ferry Ampere, is the first ship in the world to use fully battery driven and operate regularly in Norway waters. Currently the world engineers are developing new ship designs with a hybrid power, which combines two or more integrated power sources to get highefficiency power. In this paper uses a qualitative description method with reference to literature studies. The development of electricity from each
\end{abstract}


generation regarding electric power sources, automatic control and power management is the material to be discussed in this paper. The Power Management System (PMS) is a functionally integrated control system to optimize power allocation and energy distribution. PMS keeps electrical power working without any fault, disruptions or system failures while the ship is operating. PMS controls power in a safe and balanced manner between power generation and distribution of ship electrical power.

Keywords: Main Control, Shipboard Electricity, Power Management System $(P M S)$

\section{PENDAHULUAN}

Power listrik bagian penting dalam industri maritim, listrik sebagai sumber energi untuk pengoperasian dan menjalankan kapal. Instasi listrik digunakan untuk keperluan penerangan, alat komunikasi, alat navigasi, monitoring, alarm system, menjalankan motor listrik, hingga intalasi high voltage untuk keperluan penggerak utama kapal. Power listrik kapal mulai diperkenalkan pada abad 19, perkembagan sistem power listrik kapal terus mengalami evolusi hingga hari ini. Melihat catatan sejarah sistem instalasi listrik pertama kali oleh kapal komersial SS Columbia dengan instalasi listrik DC pada tahun 1880, berlanjut kepada pengembangan sistem listrik induksi motor AC menggunakan mesin diesel(Skjong et al., 2015). Kapal SS Colombia sebagai pemicu awal penelitian dan pengembangan power listrik yang dilakukan sejak abad 19 sampai dengan awal abad 20.

Evolusi power listrik oleh inovasi teknologi solid state sebagai awal era baru teknologi kapal, ditandai oleh Quin Elizabeth II tahun 1887 sebagai kapal pertama diesel electric yang terintegrasi dengan system penggerak utama. Awal tahun 2015 power listrik dengan teknologi All Electric Ship (AES) oleh kapal penumpang ferry Ampere, merupakan kapal pertama di dunia yang menggunakan fully battery driven dan beroperasi secara regular di perairan Norwegia(Skjong et al., 2016).

All electric ship menjadi revolusi pengembangan power listrik kapal dewasa ini, engineer dunia maritim terus berusaha untuk menciptakan desain kapal baru dengan sistem power hybrid. Teknologi hybrid menyatukan dua atau lebih sumber power yang terintegrasi untuk mendapatkan power dengan efiensi tinggi, system integrasi memerlukan perancangan yang komplek untuk mendapatkan hasil maksimal. Dasar penyimpanan energi hybrid dengan modular isolasi multilevel converter DC sebagai design prototype kapal MVDC (Medium Voltage DC). Algorima multi fungsi control dirancang untuk mendapatkan suplemen energi, Active Power Filter (APF), dan membatasi gangguan arus(Mo \& Li, 2017). 
Perkembangan power listrik kapal di setiap generasi memiliki metode yang berbeda dalam upaya meningkatkan sistem operasional dan memperoleh efisiensi maksimal saat kapal beroperasi, kapal dengan sistem penggerak listrik memiliki instalasi yang komplek dalam hal sistem kontrol dan sistem automatisnya. Manageman power diaplikasikan untuk mengontrol keseluruhan kerja kelistrikan, dengan tujuan untuk mengantisipasi apabila terjadi kesalahan dan menghindari terjadinya lost of power atau blackout(Schiff, 1991). Power Management System $(P M S)$ adalah bagian krusial dari sistem automatis dan sistem power listrik kapal, khususnya pada kapal dengan penggerak utama listrik(Nasrudin \& Syafiqiuddin, 2016). Power managemen memerlukan sistem integrasi antara pembangkit listrik dan sistem pembagian beban listrik untuk kepentingan pengoperasian kapal secara automatis. Hal ini penting karena digunakan sebagai pengontrol power secara tertib untuk memastikan pasokan daya listrik yang memadahi ke berbagai komponen, memaksimalkan kemampuan pencegahan listrik padam serta berfungsi untuk menurunkan biaya perawatan melalui perlindungan peralatan terhadap kesalahan dan kerusakan.

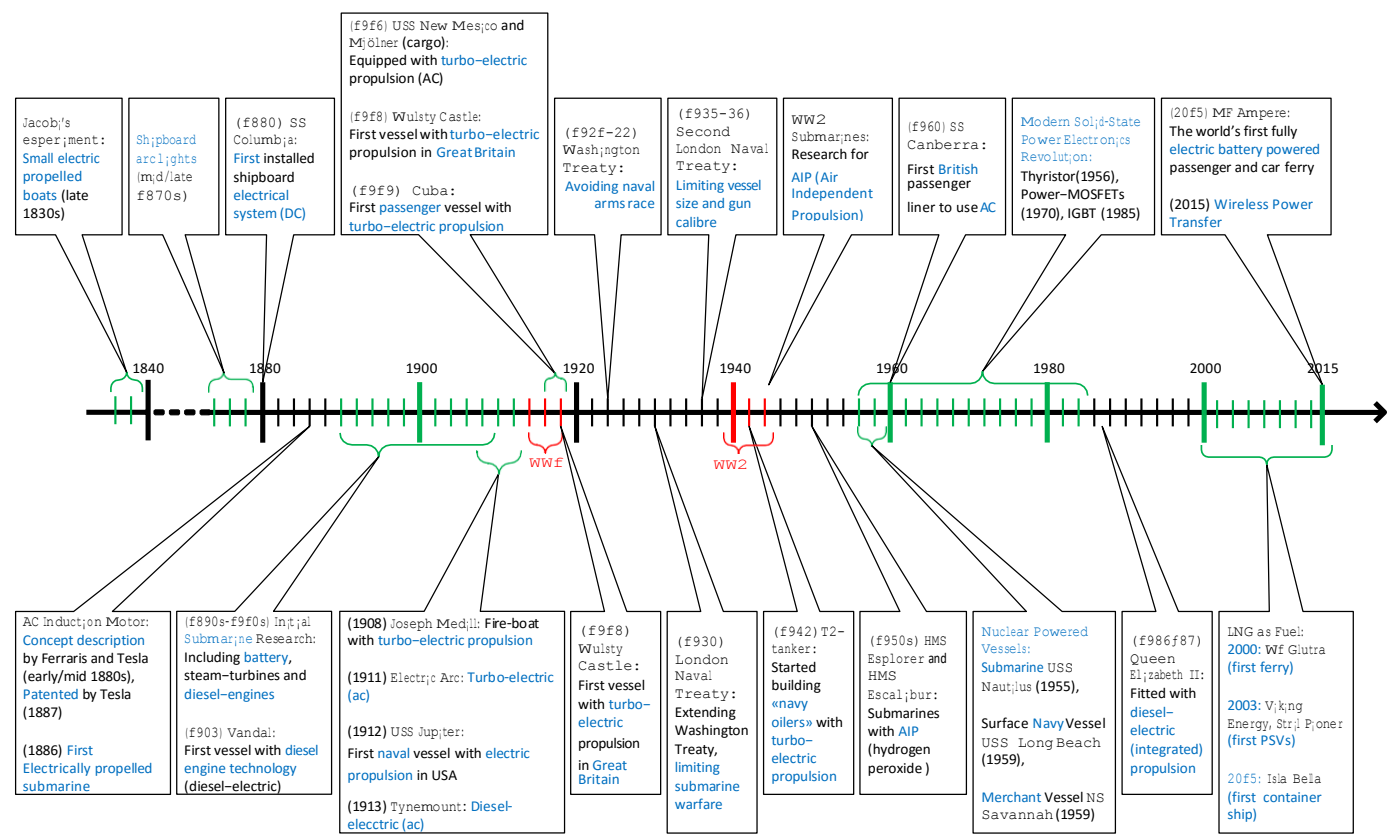

Gambar 1. Sejarah berdasarkan garis waktu perkembangan power sistem kapal(Skjong et al., 2015).

Perkembangan teknologi power kelistrikan kapal mengacu kepada sejarah perkembangan pada Gambar 1, mengelompokan sistem power menjadi tiga kelompok dan menambahkan teknologi hybrid sebagai sistem power generasi baru. Power listrik tersebut yaitu 1. turbo elektrik power, 2. diesel electric power, 3. all electric ship, 4) power hybrid. Sistem power listrik dari setiap generasi berkesinambungan dan terus dilakukan pengembangan untuk mendapatkan efisiensi tinggi sesuai dengan aturan serta regulasi dunia maritim. 


\section{A. Turbo Electric Power}

Generasi pertama untuk kapal menggunakan turbo electric dibangun setelah tahun 1900, saat itu kebutuhan permintaan penggerak listrik sangat tinggi. Power listrik tersebut hanya bisa terpenuhi dengan turbo electric, tiap baling-baling didukung oleh steam turbin generator, dengan memvariasikan kecepatan generator, dan pengendalian kecepatan motor penggerak(Doerry et al., 2015). Kapal pertama adopsi turbo electric yaitu Joseph Medill, empat tahun berikut kapal USS Jupiter tahun 1912. Kapal ini merupakan hasil percobaan, dimana kapal tersebut mengadopsi mesin diesel dan terkoneksi langsung dengan steam turbin(Skjong et al., 2016).

Kapal perang pertama yang mengadopsi penggerak turbo electric yaitu USS New Mexico tahun 1914 dengan dual voltage dan variable frekuensi generator, rate power $7500 \mathrm{Hp} 24 / 36$ pole induksi motor. Power kontrol dari integrasi sistem tersebut memberikan peningkatan yang signifikan terhadap pemakaian bahan bakar, sistem pembalikan motor yang berat dapat dilakukan dengan mudah hanya menggunakan kontrol switching circuit tanpa merubah steam system(Skjong et al., 2015).

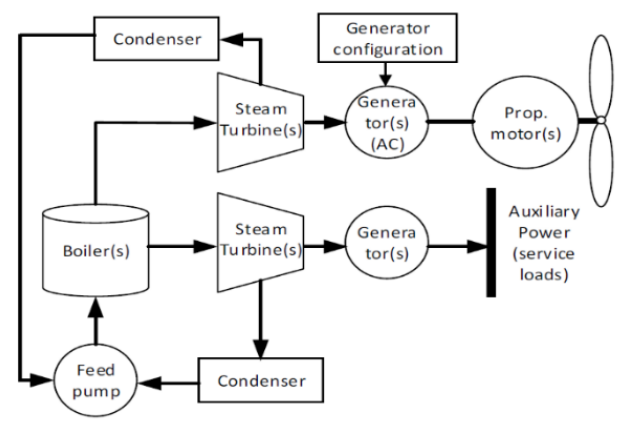

Gambar 2. Skema sistem turbo electric kapal USS New Mexico

(Skjong et al., 2015).

\section{B. Diesel Electric Power}

Kapal tanker Vandal sebagai kapal pertama yang menggunakan teknologi power diesel electric pada tahun 1903, dengan instalasi mesin diesel 3 cylinder $120 \mathrm{Hp}$ dengan kontrol transmisi elektrik(Skjong et al., 2015). Power diesel elektric bekerja sangat baik untuk kapal dengan bobot yang ringan, sistem ini memerlukan daya yang besar dari generator pembangkit untuk menggerakkan mesin utama. Sistem power oleh diesel electric terus dikembangkan hingga digunakan untuk kapal selam milik German pada masa perang dunia pertama.

Power diesel elektrik menjadi teknologi yang banyak diaplikasi untuk teknologi kapal saat ini karena kehandalan dan keserbagunaannya saat operasi(Nasrudin \& Syafiqiuddin, 2016). Sistem power listrik menggunakan pembangkitan dari generator, listrik disalurkan ke sistem distribusi untuk keperluan operasional kapal. Operasional kapal antara lain sebagai penggerak utama, keperluan komunikasi, permesinan bantu, hingga instalasi keselematan kapal(Hall, 1999). Mayoritas kapal Eropa untuk keperluan pengangkutan cargo 
menggunakan diesel electric, sistem ini terus mengalami peningkatan dan kemajuan pesat(BERG, 1926).

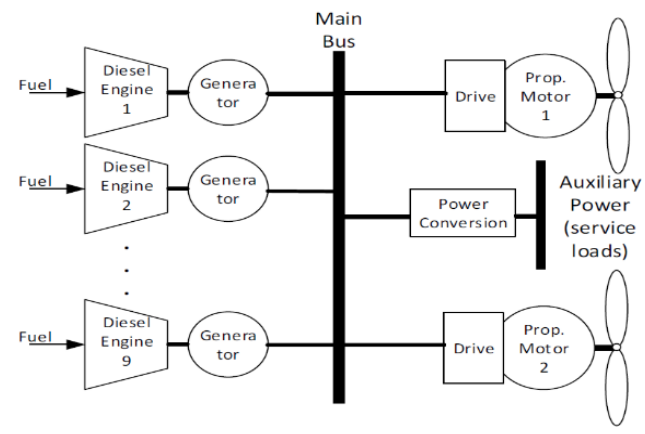

Gambar 3. Skema power diesel electric dan sistem distribusi(Skjong et al., 2015)

\section{All Electric Ship (AES)}

Sistem power kapal dengan All Electric Ship (AES) adalah kapal dengan power listrik menggunakan full battery power sebagai penggerak utama dan sistem operasionalnya. Pada Januari 2015 AES pertama di dunia oleh kapal penumpang ferry Ampere bertenaga battery. Kapal ini didesain dengan lambung ganda, panjang 80 meter dan lebar 21 meter, 7 buah kamar untuk crew kapal dan 140 kursi penumpang. Kapal dapat mengakomodasi sampai dengan 120 mobil dan 360 penumpang(Norled, 2015).

Kapal ferry Ampere dilengkapai dengan battery berkapasitas 1MW untuk menunjang kegiatan operasional penyeberangan di perairan Norwegia, kapal melakukan pengisian battery power pack menggunakan instalsi listrik darat. Desain kapal sedemikian rupa untuk mendapatkan bobot kapal yang ringan dan desain lambung optimal untuk memperoleh efektivitas energi tinggi. Dermaga khusus dibuat untuk menjaga efisiensi energi dan power battery dengan menggunakan instalasi dermaga vakum, sehingga kapal dapat sandar diam di dermaga tanpa menjalankan motor penggerak utamanya(Skjong et al., 2015).

All electric ship memiliki sistem jaringan tenaga terpadu atau disebut Integrated Electrical Power System (IEPS). Managemen power dalam AES berperan sebagai jaringan "mikro" dengan tingkat daya yang besar dan difungsikan sebagai pengontrol daya membuat IEPS - AES menjadi jaringan cerdas multi-MW yang lahir secara alami(Sulligoi et al., 2016). 


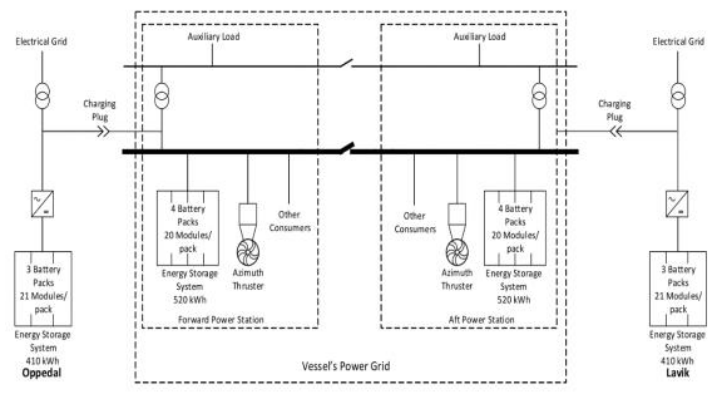

Gambar 4. Diagram integrated system kapal penumpang MF Ampere(Skjong et al., 2015).

\section{Sistem Power Hybrid}

Sistem power hybrid adalah kombinasi dari mesin, battery, penggerak daya, sumber tenaga alternatif seperti fuel cell, dan semuanya dikelola oleh EMS (Energy Management System)(Moraitakis, 2020). Kapal membutuhkan daya dalam jumlah besar untuk memenuhi kebutuhan beban yang berbeda-beda, seperti harbour tug, kapal ferry, kapal offshore atau kapal angkatan laut dapat memanfaatkan battery atau Energy Storage System (ESS) untuk mendukung power hybrid(Newman, 2019).

Pada kapal hybrid, battery merupakan bagian penting dari power sistem, tetapi dalam banyak kasus battery berfungsi menjadi power sekunder dari mesin utama. Saat ini kemungkinan besar akan menggunakan bahan bakar konvensional atau dapat beralih ke salah satu energi alternatif (renewable energy) ramah lingkungan yang sekarang ini terus dikembangkan(Latarche, 2020). Power hybrid terus diperkenalkan dan dikembangkan untuk kapal saat ini, karena berhubungan dengan rendahnya biaya produksi. Sistem power hybrid menggunakan battery sebagai penyimpan energi utama, karena teknologi battery saat ini memiliki dimensi atau ukuran volume kecil dan berat total yang lebih ringan.

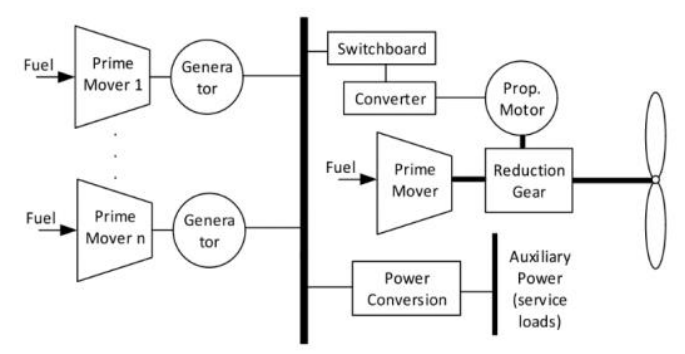

Gambar 5. Diagram jaringan sistem power hybrid(Skjong et al., 2015)

\section{E. Power Management System (PMS)}

Sistem power listrik kapal terus mengalami kemajuan dan pengembangan dari tiap generasi, hal itu terjadi atas dasar kemajuan teknologi dan tuntutan aturan atau regulasi di dunia maritim. Marpol Annex VI tentang pencegahan pencemaran polusi udara menjadi dasar untuk menciptakan kapal dengan emisi gas buang

Majalah Ilmiah Bahari Jogja 142 | http://jurnal.amy.ac.id/index.php/MIBJ/ 
rendah, serta tuntutan untuk menciptakan energi terbarukan pengganti dari minyak bumi.

Engineer di dunia maritime termotivasi untuk mengganti power konventional menjadi power sistem yang kompleks untuk menekan emisi gas buang dan menurunkan biaya operasional(Jaurola et al., 2019). Sistem power listrik dari pembangkit generator akan di distribusikan ke seluruh sistem instalasi pemakaian akhir melewati transformator, switchboard ataupun converter. Keseluruhan sistem power dimonitor dan dikontrol dengan satu sistem khusus menyesuaikan jaringan ataup sistem integrasinya. Power management system $(P M S)$ dapat berperan untuk memisahkan ataupun menyatukan jaringan dalam keseluruhan sistem otomatisasi kapal(Sørfonn, 2007). Menagemen power secara optimal menjadi kebutuhan penting dalam pengelolalan power guna peningkatan efisiensi dikapal(Anvari-Moghaddam et al., 2016).

Bentuk power managemen system dikapal yang paling sederhana adalah upaya untuk menghindari terjadinya listrik padam atau blackout(Valkeejärvi, 2005), fungsi lain untuk memastikan main breaker terputus atau trip apabila terjadi kelebihan beban pemakaian. PMS untuk memantau dan berfungsi sebagai kontrol keseluruhan dari sistem tenaga, menjadi elemen pengerintegrasi dalam integrasi penuh sistem power, sistem otomatisasi, dan sistem penentuan posisi[18]. Konsep integrasi atau Integrated Power System (IPS) dalam power managemen menjadi teknologi paling umum digunakan sebagai pengkontrol power listrik kapal saat ini[19].

PMS untuk power listrik konventional yaitu mengendalikan kebutuhan beban pemakain listrik essential dan nonessential, sistem secara otomatis mempertahankan dan memberikan daya listrik ke essential machinery saat kelebihan beban atau overload. Aplikasi power management system disesuaikan dengan jenis dan fungsi operasional kapal, saat ini jenis kapal Dynamic Position (DP) memiliki system lebih komplek.

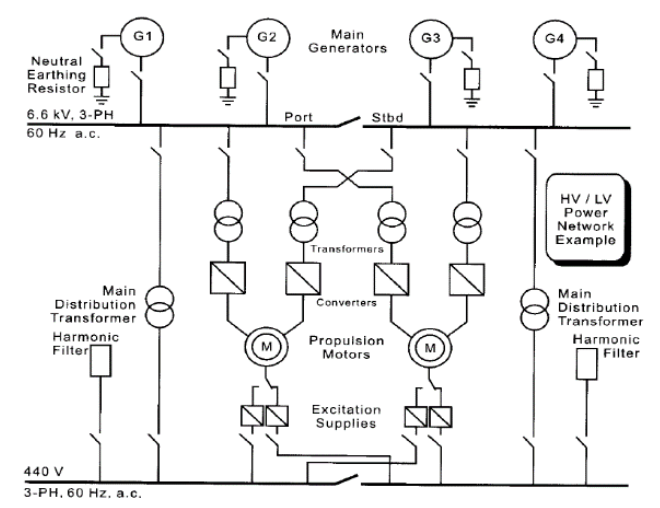

Gambar 6. Diagram power system sederhana(Hall, 1999) 


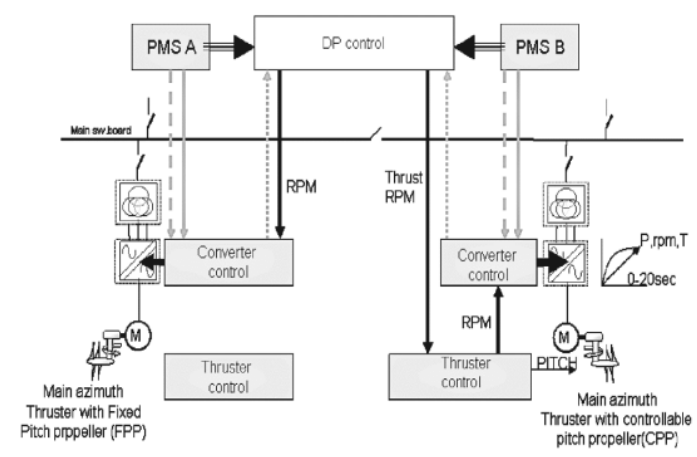

Gambar 7. Diagram power sistem DP vessel(Sørfonn, 2007)

\section{METODE PENELITIAN}

Di dalam penulisan ini untuk mendapatkan hasil yang baik digunakan metodologi deskriptif kualitatif dengan mengacu kepada studi kepustakaan. data diperoleh melalui buku ilmiah, buku manual pabrik, ataupun jurnal penelitian. Studi kepustakaan ini dimaksudkan untuk mendapatkan data awal tentang sejarah perkembangan power listrik mulai dari generasi pertama hingga berlanjut ke generasi yang sekarang. Penulisan ini mengumpulkan data untuk mendapatkan acuan dasar tentang perkembangan power listrik dari tiap generasi, beberapa hal yang di perhatikan yaitu perkembangan sumber power listrik, kontrol automatis dan managemen power dari masing masing generasi listrik kapal. Karakteristik dari power listrik dan kontrol automatis dirancang sesuai kebutuhan operasional kapal, pengembangan kontrol listrik dan model managemen power dari tiap generasi kapal menjadi menjadi dasar pemikiran dari penulisan paper ini.

\section{PEMBAHASAN}

Power Management System (PMS) fungsi secara umum mengoptimalkan sistem operasional dan menjaga power komponen essential terpenuhi sekaligus mendapatkan efisiensi bahan bakar secara maksimum, dengan asumsi lain bahwa power wajib tersedia tanpa ada gangguan dan menghindari padam. Sistem bekerja dalam hal pengawasan atau monitoring secara penuh dan full automatic control untuk mengatur aliran energi listrik dari sumber pembangkit hingga titik terendah yaitu pemakai listrik. Prinsip utama mewujudkan power listrik yang memenuhi kriteria saat operasional mengacu kepada 7 hal, yaitu: 1. Safety, 2. Reliability, 3. Accessibility, 4. Availability, 5. Impact of environment, 6. Economic, 7. Esthetic.

Prinsip dasar diatas memiliki arti yaitu power listrik musti aman, power listrik handal saat beroperasi, power listrik mudah untuk digunakan siapapun dan kemudahan akses perawatan, power listrik tersedia sepanjang waktu, power listrik ramah lingkungan, power listrik dengan nilai efisiensi tinggi dalam hal perawatan dan perbaikan, terakhir yaitu menciptakan power listrik dengan prinsip estetika atau keindahan dalam instalasinya.

PMS sebagai kontrol penting untuk ketujuh prinsip dasar power listrik dalam mengontrol dan membandingkan jumlah beban listrik dengan ketersedian 
power listrik dari unit pembangkitan secara tepat aman. Pada saat ketersedian power listrik menurun atau melemah sedangkan beban listrik semakin tinggi, maka PMS secara automatis menjalankan pembangkit lain untuk mendukung kinerja dan menjaga ketersediaan power listrik. PMS kontrol menjaga dan menghindarkan power dari blackout melalui deteksi awal dan cepat dalam menganalisa kondisi beban listrik. Kontrol secara cepat mereduksi kebutuhan beban listrik, mengalokasikan power untuk essential machinery dan memberikan respon lanjutan untuk menambah sumber power.

Penyebab gangguan terbesar ketersediaan power listrik diakibatkan oleh mesin penggerak mengalami shutdown(Radan, 2008). PMS kontrol merespon setiap data yang ditampilkan oleh generator, baik data dari sisi mesin dan sisi alternator. Penyebab terjadinya mesin mengalami breakdown atau shutdown antara lain yaitu:

1. Kegagalan sistem bahan bakar, yaitu jalur bahan bakar buntu, filter kotor, pompa bahan bakar rusak, injector tidak bekerja maksimal, terdapat kandungan air di dalam bahan bakar.

2. Kegagalan gerak mekanik, yaitu kehilangan tekanan untuk air pendingin, tekanan minyak lumas, tekanan udara masuk sistem, overspeed atau putaran mesin berlebih, dan temperatur tinggi untuk air pendingin ataupun minyak lumas.

3. Kegagalan sistem kontrol, yaitu transmitter tidak menampilkan nilai tekanan dan temperatur secara benar, adanya tekanan berlebih didalam ruang crankcase, sensor mendeteksi adanya gas berbahaya di ruang crankcase, kehilangan sinyal input dan output dari sensor.

4. Kesalahan operator / engineer, yaitu kesalahan pada saat proses parallel dan proses pembagian beban tidak tepat sehingga sistem trip oleh revers power protection.

Power managemen secara konsep awal sebagai pengendali energi dan bahan bakar minyak serta gas, namun saat ini managemen power berkembang untuk mengendalikan teknologi power baru dari energi terbarukan(Fossen, 2002). Managemen power dikelompokan menjadi 3 bagian untuk sistem pengendaliannya, yaitu:

1. Manajemen pembangkit listrik: monitoring terhadap frekuensi dan tegangan, monitoring pembagian beban aktif ataupun pasif, pengendalian start dan stop power pembangkitan bergantung terhadap beban listrik, monitoring sistem parallel dan pembagian beban berimbang, monitoring terhadap parameter atau poin-poin kritikal, monitoring terhadap transformator pembangkitan listrik, pengendali mode kontrol pengoperasian, mengatur proses start power pendukung saat blackout.

2. Manajemen load atau beban: monitoring beban dan integrasi pembatasan daya pada semua komponen beban, mengatur pelepasan aecara automatis setiap beban nonessential, mengatur aliran listrik berimbang ke seluruh panel, pengaturan $\mathrm{MCB}$ breaker dan interlock berdasarkan distribusi daya yang tersedia 
3. Manajemen distribusi power: monitoring sistem aliran power setiap panel distribusi, monitoring terhadap fault atau kesalahan jaringan distribusi, monitoring parameter kontrol dan nilai low insulation, monitoring konfigurasi sistem dan urutan kontrol sebagai dasar pengaturan ulang dalam konfigurasi distribusi. Sistem managemen distribusi power menjalankan proses konfigurasi ulang untuk mendapatkan kontrol yang sesuai dan benar saat kapal beroperasi.

Sistem pengendalian operasional power kapal oleh PMS kontrol yaitu:

1. Pengendalian start-stop dan safety device generator.

2. pengendalian kontrol automatis paralel dan sinkronisasi generator.

3. Pengendalian kontrol automatis share dan auto release beban listrik.

4. Pengendalian pencegahan power blackout.

5. Kemampuan menyediakan power listrik untuk penggerak utama dan beban pemakaian berat

6. Pengendalian auto trip atau preference trip relay,

7. Pengendalian frekuensi dan pengaturan mode operasional kapal.

8. engendalian transfer atau perpindahan sumber power dan beban oleh shaft generator.

Kontrol pengendalian pencegahan power listrik blackout oleh PMS adalah hal penting dan utama. Salah satu hal yang menyebabkan blackout yaitu adanya kelebihan beban dimana generator tidak sanggup memenuhi kebutuhan power yang diperlukan. Peran PMS untuk memantau setiap waktu beban listrik berjalan, kontrol akan cepat merespon dan mengambil tindakan guna mengurangkan beban dan menyalakan generator sebagai power penunjang. Salah satu bentuk PMS yang digunakan pada kapal Dynamic Position (DP) adalah sistem dimana power terbagi atas dua sisi yaitu PMS A dan PMS B. Power sistem kapal beroperasi secara terpisah antara PMS A dan B dan terdapat tie breaker sebagai penghubung diantara keduanya. Kontrol tie breaker berfungsi sebagai pemutus dan penghubung jaringan antara PMS A dan B, sebagai contoh apabila PMS A failure maka beban listrik akan diambil alih PMS B secara cepat (Gambar 8).

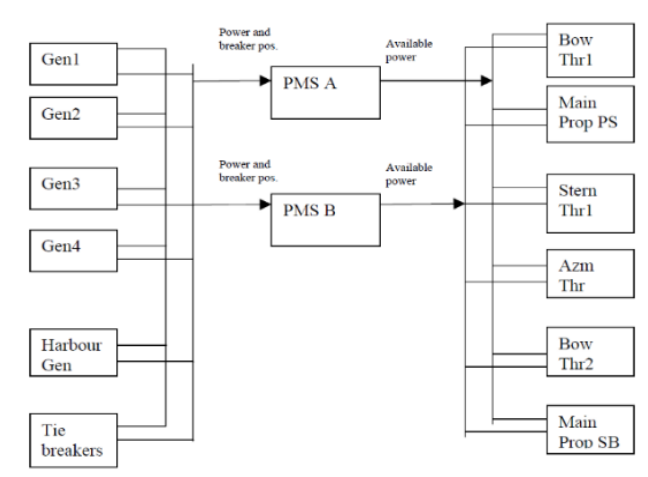

Gambar 8. PMS Topology(Sørfonn, 2007). 


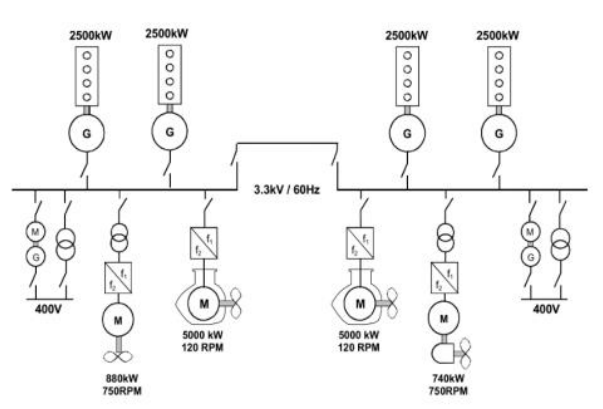

Gambar 9. Diagram single line dengan dua-split power plant pada Offshore Supply vessel, terdiri dari empat set generator, dua azipods, satu azimuth thruster, satu tunnel thruster(Fossen, 2002)

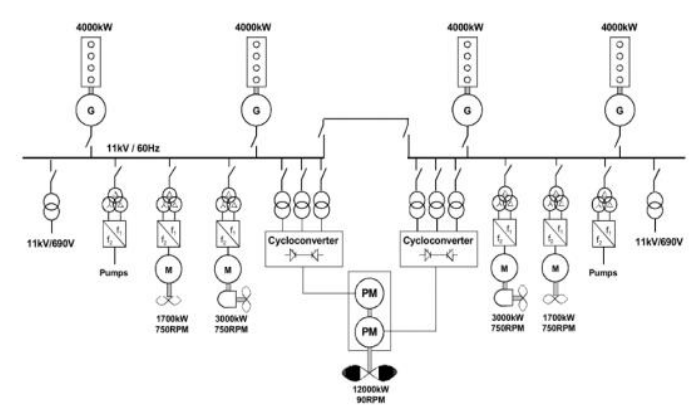

Gambar 10. Diagram single line dengan dua-split power plant pada kapal Tanker, terdiri dari empat set generator, satu mesin utama, dua azimuth thruster, dua tunnel thruster(Fossen, 2002)

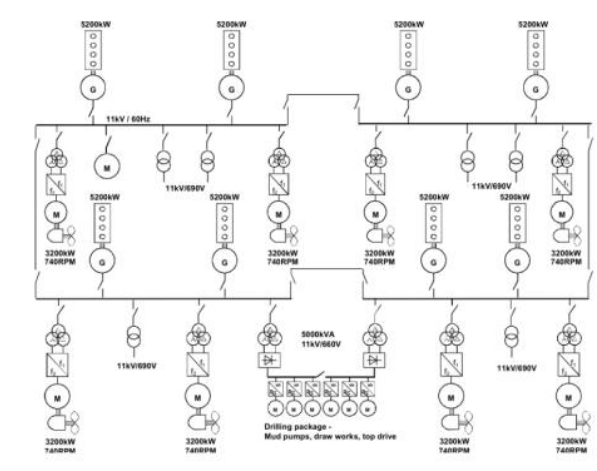

Gambar 11. Diagram single line, empat-split power plant pada drilling rig, terdiri dari delapan set generator, delapan azimuth thruster(Fossen, 2002) 


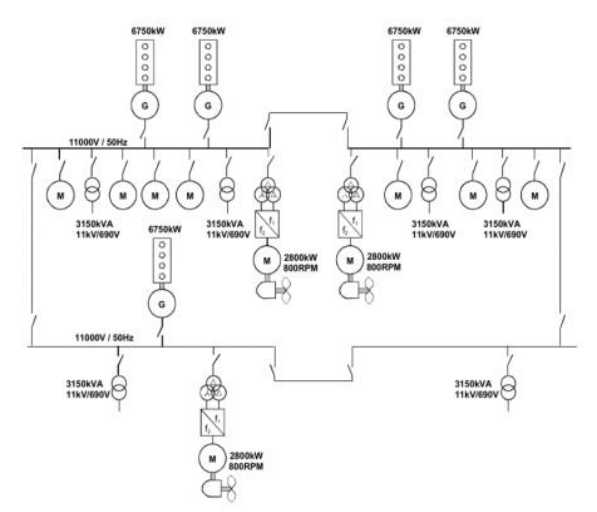

Gambar 12. Diagram single line, dua-split power plant pada FPSO, terdiri dari lima set generator, tiga azimuth thruster(Fossen, 2002)

\section{PENUTUP}

\section{Kesimpulan}

Power listrik kapal diperkenalkan pada abad 19, melihat catatan sejarah power listrik dimulai pertama kali oleh kapal komersial SS Columbia berlanjut ke power listrik induksi motor AC menggunakan mesin diesel. Evolusi power listrik dengan inovasi teknologi solid state sebagai era baru teknologi kapal oleh Quin Elizabeth II, sebagai kapal pertama diesel electric yang terintegrasi dengan sistem penggerak utama. All Electric Ship oleh kapal penumpang ferry Ampere diperkenalkan tahun 2015, adalah kapal pertama di dunia yang menggunakan fully battery driven untuk seluruh sistem operasionalnya. AES sebagai revolusi power listrik kapal, pengembangan power kapal saat ini yaitu desain kapal baru dengan menggunakan power hybrid. Power Management System (PMS) sebagai bagian krusial sistem automatis power listrik kapal saat ini, managemen power merupakan sistem terintegrasi antara pembangkit listrik dan distribusi beban. Power listrik untuk operasional wajib memenuhi 7 prinsip dasar, yaitu: safety, reliability, accessibility, availability, impact of environment, economic, esthetic. Konsep awal managemen power sebagai pengendali energi bahan bakar minyak dan gas, namun saat ini berkembang untuk mengendalikan teknologi power baru dari energi terbarukan (renewable energy). Managemen power dibagi menjadi 3 kelompok untuk sistem yang dikendalikan, yaitu managemen power pembangkit listrik, managemen distribusi pembagian beban dan managemen distribusi power. Setiap kapal memiliki manageman power yang berbeda, disesuaikan dengan fungsi operasional kapal. Power hybrid kapal banyak dikembangkan saat ini, untuk kedepan perlu pembahasan lebih lanjut tentang pengembangan PMS Hybrid dalam integrasi mengontrol Energy Managemen System (EMS), Energy Storage System (ESS), Battery Energy Storage System (BESS).

\section{DAFTAR PUSTAKA}

Anvari-Moghaddam, A., Dragicevic, T., Meng, L., Sun, B., \& Guerrero, J. M. (2016). Optimal planning and operation management of a ship electrical 
power system with energy storage system. IECON Proceedings (Industrial Electronics Conference), 2095-2099. https://doi.org/10.1109/IECON.2016.7793272

BERG, E. (1926). Electric Propulsion of Ships. Journal of the American Society for Naval Engineers, 38(2), 346-453. https://doi.org/10.1111/j.15593584.1926.tb05548.x

Doerry, N., Amy, J., \& Krolick, C. (2015). History and the Status of Electric Ship Propulsion, Integrated Power Systems, and Future Trends in the U.S. Navy. Proceedings of the IEEE, 103(12), 2243-2251. https://doi.org/10.1109/JPROC.2015.2494159

Fossen, T. I. (2002). Marine control systems. Book, 558. http://scholar.google.com/scholar?hl=en\&btnG=Search\&q=intitle:Marine+C ontrol+Systems\#1

Hall, D. T. (1999). KNOWLEDGE MARINE Second Edition.

Jaurola, M., Hedin, A., Tikkanen, S., \& Huhtala, K. (2019). Optimising design and power management in energy-efficient marine vessel power systems: a literature review. Journal of Marine Engineering and Technology, 18(2), 92101. https://doi.org/10.1080/20464177.2018.1505584

Latarche, M. (2020). Battery and hybrid ships. How do they work and how many are in operation. ShipInsight. https://shipinsight.com/articles/battery-andhybrid-ships-how-do-they-work-and-how-many-are-in-operation/

Mo, R., \& Li, H. (2017). Hybrid Energy Storage System with Active Filter Function for Shipboard MVDC System Applications Based on Isolated Modular Multilevel DC/DC Converter. IEEE Journal of Emerging and Selected Topics in Power Electronics, 5(1), 79-87. https://doi.org/10.1109/JESTPE.2016.2642831

Moraitakis, G. (2020). Increasing efficiency through hybrid technology (p. 10). safety4sea. https://safety4sea.com/cm-increasing-efficiency-through-hybridtechnology/?_cf_chl_jschl_tk_=84dd7e3a61ad7aa09a4c2b1f0d4842968ed 57cc0-1619752226-0-AVJtprK2uduP4E4QUSgbqiN5zXHEQT16m3LmMTLAAHiVYkiyQP8iM4ANA7ad7_4bXkeCxzhGP MTechd9WE-Put485YS4XhZ2AF4sJ0eHN

Nasrudin, I., \& Syafiqiuddin, C. S. M. (2016). Design Study of Power Management System for Parallel Operation of Generator Set of a Ship's Diesel Electric Power Plant. Journal of Advanced Research in Fluid Mechanics and Thermal Sciences ISSN, 20(1), 2289-7879.

Newman, N. (2019). Hybrid ships that voyage across the deep blue could very well be the key to unlocking environmental sustainability. Engineering and Technology. https://eandt.theiet.org/content/articles/2019/01/hybrid-shipstake-to-the-high-seas/

Norled. (2015). Ampere Electric Powered Ferry. ShipTechnology. https://www.ship-technology.com/projects/norled-zerocat-electric-poweredferry/

Radan, D. (2008). Integrated Control of Marine Electrical Power Systems. In PhD Thesis

NTNU. https://pdfs.semanticscholar.org/b770/71c49cf7425e23a386e5d90b779cd21e 
242e.pdf\%0Ahttp://folk.ntnu.no/assor/PhD Thesis/Phd_Radan_NTNU.pdf

Schiff, A. J. (1991). Power Systems. Earthquake Spectra, 7(1_suppl), 57-68. https://doi.org/10.1193/1.1585650

Skjong, E., Rødskar, E., Molinas, M., Johansen, T. A., \& Cunningham, J. (2015). The Marine Vessel's Electrical Power System: From its Birth to Present Day. Proceedings of the IEEE, 103(12), 2410-2424. https://doi.org/10.1109/JPROC.2015.2496722

Skjong, E., Volden, R., Rodskar, E., Molinas, M., Johansen, T. A., \& Cunningham, J. (2016). Past, present, and future challenges of the marine vessel's electrical power system. IEEE Transactions on Transportation Electrification, 2(4), 522-537. https://doi.org/10.1109/TTE.2016.2552720

Sørfonn, I. (2007). Power management control of electrical propulsion systems. Dynamic Positioning Conference, Houston. http://dynamicpositioning.com/dp2007/design_sorfonn.pdf

Sulligoi, G., Vicenzutti, A., \& Menis, R. (2016). All-electric ship design: From electrical propulsion to integrated electrical and electronic power systems. IEEE Transactions on Transportation Electrification, 2(4), 507-521. https://doi.org/10.1109/TTE.2016.2598078

Valkeejärvi, K. (2005). The ship's electrical network, engine control and automation. Money, 19-24. 